\title{
The Role of the Mass Media in the Nigerian Electoral Process
}

\author{
Fidelis Chuka Aghamelu* \\ http://dx.doi.org/10.4314/ujah.v14i2.8
}

\section{Abstract}

This paper focuses generally on the role of the mass media in Nigerian electoral process as it pertains to overall development of Nigeria. The background is the recognition of the central role of the media in political and social affairs as a natural outcome of its unlimited communicative strength and outreach. The statement of problem is anchored on the wide spread negative image of the media in electioneering campaigns in Nigeria's political history. The objective of this paper is to readdress media practice in Nigeria to its fundamental ethical journalistic foundation as basis for positive contribution to national integration. It is also aimed at the examination of both external (official) and internal obstacles that hinder the realization of the goal. This paper uses the method of comparative phenomenological analysis to examine the performances of the media in Nigerian electoral process with regard to its fundamental roles to inform, educate, entertain and monitor in the electoral process.

\section{Introduction}

The history of elections in Nigeria generally has afforded us the golden opportunity of assessment of the divergent roles of the media in Nigeria political process within the framework of our national political goal. The issue and question of education, information, mobilization and monitoring has become a very crucial factor in the realization of the national objectives in the context of the electoral process. This is as a result of the ugly incidences of various forms of electoral 
malpractices which have repeatedly threatened the possibility of credible elections and national integration in Nigeria. Though the issue at stake is the responsibility of all stakeholders in the body politic, there is however, a rationale in assigning this responsibility as a primary concern of the mass media on the ground of professional competence as the fourth estate of the realm.

It has therefore, become very important to assess the roles of the mass media in the electoral history of Nigeria. To what extent has the Nigerian media discharged its statutory functions towards achieving a positive political national agenda? Iredia $(2007: 12)$ the former Director General of Nigerian Television Authority (NTA), states the problem in this regard very clearly that,

the people must be assisted to premise their choices of rationality and vote wisely during elections. They must have all information that is needed to elect the right candidates who can ensure good governance. Where such public awareness is lacking, those of us in the media must accept a share of the blame of failed elections in Nigeria.

This paper presumes an understanding of the meaning of election or electioneering campaign in politics as a periodic selection of government representatives of the people at various levels of governance by the electorate themselves.

\section{Constitutional and Moral Basis of the Role of the Media in Politics and Governance}

Dukor (1999:283) anchors the assessment of the role of the media in politics on the "fundamental right to receive and impart information". This becomes not only the standard for assessing the role of the media, but also "the neglected role 
of... states to uphold the ethics of the right to know... in an ideal democracy". This quest to propagate the inalienable right to know and impart information was influenced by the,

Natural law doctrines, the articles of French revolution, the precepts of American declaration of independence, The United Nations Declaration of peoples' and Human Rights, African Charter on Human and Peoples Right (Ibid).

For instance, the "African Charter on Human and People's Right" adopted in 1986 and ratified in July 1990, states among others that "every individual shall have the right to receive information,... shall have the right to express and disseminate his opinions within the laws".

It has become very pertinent to examine the extent to which these precepts of the fundamental rights of man have been observed in the context of Nigeria's politics and media practice especially in the area of democratic elections. It must be emphasized that any talk of democracy without the right to receive and impart information is empty. Nigeria has a background of liberalism which dictates free flow of information, yet the country's media according to Dukor have been for the most part, performing, within air of regulated freedom. Since independence, there has been several factors encumbering the right to know about government policies. This has been the case mostly during the military inter regnum. For instance, a good number of decrees were put in place to hinder press freedom and jeopardize the public right to know and receive information. Dare, L (1985) gives a rundown of such decrees to include,

Newspaper (Amendment Act) 1964, the official secrets Acts 1962, the Defamation Act 1961, public officers (protection against false Accusation) Act No. 11 1976, the newspaper 
prohibition circulation act 1967 and public officers (protection against false publication)

Decree No. 4 1984).

On the other hand, Dukor (1999; 287), opines that there has been a democratic flowering of the independent press which has generally accompanied moves towards democracy and respect of human rights. But regrettably, the practice of journalism in Nigeria is bedeviled by some unethical problematic.

The media, hitherto is politically polarized interms of axis, ethnic loyalty, and sectional party and selfish interests (Ibid).

This is against the backdrop that the media is one of the institutions that sustain democracy. It is on this basis that Dukor examines the relationship between the state and the media in Nigeria and observes that it has been that of mutual distrust.

According to the Nigerian press council, the Nigerian media,

have fallen victim of manipulations by government and politicians. We are being witnesses to the fallen standard of journalistic profession and its negative contributions to nation building through a hackneyed uncouth and indiscrete reporting of events and issues... ethnic polarization of media houses and consequent undue influence on power and political tussles. As a result, in moment of crisis, the media become ready tools for those actively involved in the crisis of power.

One of the main constitutional roles of the media in a democracy is to objectively monitor governance while remaining consistent, preserving and objective stance in 
holding those involved in the democratic process accountable to the people. These include those with executive, legislative and judicial functions in the polity together with all institutions of governance and democracy. Dukor's argument is that the mutual distrust existing between the state and the media in Nigeria, has negated the benefits of the fundamental right to know and impart information. This paradoxical trend in Nigeria is for the state to negate its constitutional relationship to the media and citizenry. The consequence of this situation is that the development of the entire society is undermined with regard to the right to know and impart information. This tends to widen the gap in communication between government and society.

It belongs to the responsibility of the media in Nigeria to for instance, inform the Nigerian public on how "vested interests have become policy matters, how obvious facts have hidden under honorific national interests, how violence has been condoned as law and order, how cold-blooded murders have been perpetuated as encounters" (Dukor, p. 288). The role of the media in any democratic society is to educate, to inform and to entertain people.

However, they have to be vigilant watchdogs of public interest and under no special circumstances should they demean themselves into acting as lapdogs for establishment. Even in very normal and placid times, the media is expected to be a keen observer, alert and concerned even though non-intruding and nonpartisan in governance. (Ibid).

\section{Media and Politics in Nigeria: A Historical Perspective on the Problematic}

At independence, African leaders borrowed the authoritarian attitude in respect of the curtailment of press freedom from 
regimes of Eastern and central Europe "action seemingly justified by the urge to fight against western imperialism and colonialism". This according to (Becker, S. and Lower, E 1976) gave rise to,

the culture of one voice... institutionalized ...

one voice culture entailed that there be only one

official press... the effect (of which) was that

authoritarianism grew into conformist press.

While during the colonial struggle, indigenous newspapers became a rallying dissent point against colonial iniquities and injustices to "propagate political ideas, to fight colonial injustices, to seek and demand freedom, to protect the people's interests, and to educate them about the present and the future" (Dare, L (1985), the reverse became the case on attainment of political independence. However, as a colonial heritage, when in 1953 the motion for self-governance was made by the Action Group, Sir John Macpherson, the then colonial Governor, made a radio broadcast castigating the party. When Chief Obafemi Awolowo, the leader of the party, sought a "right of reply" to the broadcast, the management of the radio service rejected the request on the directive of the colonial government. According to scholars this introduced into the Nigeria media the culture of imbalance and partisanship. According to Adedeji, A. (1991), in 1961 the same government media were used to announce landslide victories for the ruling political parties in the regional elections. According to, it was on Adedeji, A. (1991), the contrary a public knowledge that the victories attributed to the Northern People's Congress (NPC) in the north and the National Council for Nigeria and Cameroon's (NCNC) in the East were achieved using in part all forms of electoral chicanery, political intimidations and even coercion including imprisonment of opposition leaders. 
In 1964, the government media again were used to announce that over fifty percent of the candidates of the ruling party were returned unopposed without voting in many places in the election into the federal house of representative that year. This again was contrary to the fact as Dare (1989:6) observed that Nigerians were aware that the announcements were false, because in some cases, the returning officers disappeared and could not be contracted after receiving papers for the official candidates. In 1965 Okolo (1993:16) noted that different versions of the results of the same election held in the western region in October of that year were announced by different media houses operating in Ibadan the regional capital. The affected media were Eastern Nigerian Broadcasting Services (ENBS), the Western Nigerian Broadcasting Service (WNBS) and radio Nigeria.

In the second republic civilian government, the newspaper and electronic media were owned by different state governments and the federal government. These media were therefore loyal to the governments in control of their states. This situation though it has the tendency of promoting healthy rivalry further dampened the image of the media. "This is because, the practitioners of journalism wrote reports and news in their preconceived images, thereby destroying their integrity and profession leaving behind a vulgarized journalism" (Dukor p.286). The implication of this scenario of unprofessionalism is that the Nigerian media became concerned not with "the truth, but with rumours". This has largely led to the opinion that journalism as is practiced in Nigeria is a "hogwash of exaggerations and speculations", where, facts are distorted to suit the ends of those who own the media". Therefore, it can be argued that journalism in Nigeria with regard to its constitutional roles is not scientific. This position is authenticated by many other findings, especially with regard to election in Nigeria. 
For instance, Egbon, M. (2004) in his study of the 1983 elections alleges

That television houses made it impossible for any politician opposed to the government in power to appear on the screen and when he appeared at all, his picture would be distorted and television mechanism upset in order to deliberately render his voice inaudible.

As Okolo opines, Nigerian political parties and their functionaries have always been known for using the media in an unwholesome manner. In 1983 for example, the incumbent state governors used the media controlled by them to announce their own re-election. The announcements by the governors were made well before the Electoral commission could include the collation of votes cast at the same election (Alao, D (1992). In 1991, the Governorship election held in Edo on December 14 was nullified because the state owned broadcasting service breached the rules on political broadcast (Alao, D (1992). A report of the European Union (EU) Election observation mission in respect of the 2003 general elections opines that media performance during the Nigerian elections was flawed, as it failed to provide unbiased, fair and informative coverage of political parties and candidates contesting the elections. Federal and state owned media were biased in favour of parties and candidates in power.

A cursory insight into the history of elections in Nigerian political development suggests a verdict of irresponsible media. This is because the media has unduly left itself to the manipulation of the negative factors in Nigerian election and politics, thereby, becoming irresponsible. First of 
these influences is the influence of tribalism in political party formation.

Right from the period before and after independence, till date, political parties in Nigeria are formed along ethnic and tribal lines. These parties have championed parochial and ethnic interests at the expense of national unity and stability of the polity. According to Agba (2007:70).

From the NCNC, AG and NDC of the precolonial days and the first republic (1951-1966), through the NPN, NPP, GNPP (1979-1983) of the second republic and the third republic and the NRC and SDP (1991-1993) of the botched fourth republic,

and even to the present day PDP, APGA, ACN, CPC and others (1999-2011), political parties formation has been an ethnic affair.

As a result of this tribalistic scenario, Marcia grant, as reported in Edogbo (1994:33), carried out a comprehensive study of the relationship between the press and the political system in Nigeria and discovered that the character of political reporting and commentary was entirely dependent on media ownership structure and the owner's relationship with the political system. He therefore concludes that most newspapers often spoke for one political party or one region against another, which meant that the press has always acted not as impartial estate, but as mouthpiece of the political divisions in Nigeria. Also Mohammed, J. (1994), observes that much did not change in the role of the media with regard to its impartiality in subsequent democratic elections and electioneering campaign. For him press partisanship has always manifested in political reporting.

As Agba (2007:71), points out, these scenario represents a failure on the part of the media to engage in thorough analysis of party manifestoes and de-emphasis of 
ethnic politics. Agba's verdict on electioneering campaign in Nigeria is that of the absurd. According to him, electioneering campaign seem to portray a consortium of insincere political figures, whose failure to keep promises dampens the spirit of the electorate and the masses. He concludes that electioneering campaign in Nigeria is characterized by electoral dirtiness and insecurity. Consequently, Uzuegbunam (1993:49), opines that these have been the basis for most of the cases of irregularities, election malpractices, misappropriation, mismanagement and insensitivity to the masses. To this effect, Stappel (1973:6), has called on the media to work on Nigeria's political culture.

Unfortunately, this unwholesome use of the media which has become a norm in Nigeria, usually brings with it untold mayhem, chaos and political instability. In 1965 for instance, following the conflicting election results announced by the media, political opponents in the Western Region engaged themselves in what was referred to as "OPERATION WETE", a process of setting property ablaze with petrol (Agba, P.C (2007) Many lives and much property were lost in that exercise. In 1983, the Federal Television Station in Abeokuta, Ogun State, was set ablaze ostensibly to show public dissatisfaction with the station's broadcast during the election. Similar incidents were recorded in different parts of the country. The root cause of these problems was traced to the media by some politicians. The implication is that election rigging in Nigeria usually attracts negative reactions from the public, reactions which become very destructive when exacerbated by media publication of inaccurate information or controversial results. What this suggests is that it is time to search for strategies that can improve the performance of the nation's media, particularly in matters of politics and elections. The media should help to build enlightened electorate. Public enlightenment is a pre-condition for free and fair elections. As 
Agba (2007), points out, the attainment of democratic governance in a society is contingent on the psychological readiness and positive mental state of the citizens.

\section{The Media in Effective Electioneering Campaign Reportage in Developing Context}

The fore knowledge of Nigeria's unhealthy political culture should form the springboard for media action. Its present status as an elite media, that is, the preserve of the powerful and the harbingers of government, does not augur well for the media, government and society. Agba (2007:261) argues that the media should go back to the concept of journalism in public interest to be able to discharge its proper role in times of election. In this regard, the very first task of the media is how to make politicians respect people's right to candid electioneering. In this regard, news should not mean alienating the audience and keeping the electorates groping in the dark. According to Nwaozuzu (1997:87), electioneering campaign reportage should seek out relevant truths for the people who cannot witness or comprehend the events that affect them. Cohen (1970:27), collaborates the above viewpoint and clearly defines its implications for good political culture. According to him news has gotten so complex that mere reportage is not good any more. What is required is for the journalist to add analysis to campaign news. This implies that the media must interpret campaigns in the light of the electoral needs of the people, that is, implications and actions to people and to realization of a vibrant political system.

This simply means directing the goals of electioneering campaign to the desirable goal of responsible democratic principles that recognize the sovereignty of the people's votes. The media, Agba points out, should aim towards getting all political actors to truly believe in one Nigeria, to accept the 
rules which are made to guide the conduct of elections. These form the purview of media self-examination. Agba (2007:71), acknowledges the fact that electioneering campaign for political power in Nigeria has become part of the problem of national cohesion and integration. It has therefore, become "part of a profound socio-political rot". Electioneering campaign has become part and parcel of national development, in that most often, it has become "intriguing and intricate and bloody", as ethnic rivalry and struggle to get big chunk of the national cake is a recurrent political experience".

It is also an acknowledged fact that the mass media has a very important role to play in channeling electioneering campaign to serve the goal of national development. This is because the mass media is described as "a pivot of social interaction, seeking to use the power of mass information to solve the problem of national cohesion and integration, which are both critical to the growth of healthy electioneering campaign" (Agba: 2007:69). But to achieve the above objective, the mass media in Nigeria needs to solve its internal problem of cohesion and integration; "for there are as many media houses as there are many political interests. There are therefore, external and internal obstacles in the realization of the positive role of the media in electioneering campaign. In all, it is argued that the media require a political ideology that guarantees freedom of speech and access to information. This is particularly true as noted by Kalu (1985:14), that

We can depend on free speech and democratic ideas only if we accept that free flow of information is necessary for the propagation of political freedom especially during election.

This argument hinges on the fact that without a free press, the reporter becomes a public servant, a stooge of the powerful and a robot who acts out the scripts of callous 
politicians. Under this scenario, the media fails to become worthy representatives of the people.

Apart from the issue of critical self-examination of the role of the media at elections, the media also shares in the responsibility of channeling the electoral process towards the desirable goal of national development and integration. For instance, Kalu (1985:19), points out that "the ordinary expectation is that the mass media will focus on serious matters that portend serious consequences for the people and their political choices". For Akpan, E. (1985) the media must clarify issues during campaigns, bring aspirants close to the electorate, and teach the differences between party and candidate to enable the electorate make a wise choice. If this is not done "political reporting will lose much of its luster if it does not deal adequately with such issues as national problems, policy guidelines, party programme and government performance" (Kalu 1985:19). The mass media should enable the electorate to analyse campaign messages of politicians. Media focus should be to set the correct political agenda for the audience and not allowing the politicians to do so Ciroma, A (2005)

Journalistic writing ... commentaries, editorials, articles, reviews, columns, broadcast discussion ... should raise and answer pertinent question that help to elucidate confusing issues, particularly those relating to policies and leadership... .

Agba argues that questions like these and more could suggest workable techniques that can help Nigerians deal decisively with problems of corruption, ethnicism, lack of accountability and weak checks and balances in government.

As pointed out earlier, the political trend in Nigeria with regard to the electoral process demands specialist political reporters. This should cover critical areas as knowledge of 
legal issues in campaign reporting, investigation and balanced judgement that allows the establishment of gathered facts. It is on this note of expertise that general reporting can be said to have become increasingly handicapped. As Louis (1971:151) puts it, thorough voters' guidance should be the heart of campaign reporting by the mass media. To achieve this objective, the reporter must do with absolute detachment. He should instead carry critical and objective analysis of candidates with the aim of educating the electorate. In this capacity of impartiality, the campaign reporter acts as a catalyst between the candidates and the electorate. Becker, S. and Lower, E (1976) gives an articulate summary of the functions of the mass media in electioneering campaign as follows" reporting and interpreting events, defining issues, portraying personalities, investigating support"

There is a very serious angle to the public enlightenment dimension of the role of the mass media in the electoral process. As Agba, P.C (2007) observes, people are eager to join the plethora of electoral malpractices without realizing that it is they who will be victims of bad government resulting from involvement in electoral fraud. Agba, P.C (2007) argues that $43 \%$ of our population is still illiterate, a rather large group which requires the special attention of the media. For this group, it is necessary that every electoral information be repeatedly disseminated and in the local languages too. This is why the media must go beyond the mere dissemination of information and engage in political education. For example, it is necessary to educate non-voting population on why they cannot vote instead of scaring them with numerous penalties for breaching the electoral law. As for the voting population, voter education programmes must be userfriendly, especially for the disadvantaged groups like the nonliterate and physically incapacitated. The programmes of 
voters' education must offer opportunities for all issues at stake in election to be highlighted and explained. These include basic issues such as who can vote or contest an election, date of the election and where to vote.

Iredia (2007), opines that electoral commission does not have the capability to undertake voter education. According to him, there is a big difference between voter education and the image-making ventures which many information departments of electoral commissions undertake. "The powerful channels, the most potent strategies and the technical format for effective public enlightenment belong to the media".

The media's role in an election also extends to monitoring of the electoral process. To this extent, media's emphasis should no longer be limited on when and how the leaders voted or were registered. How the entire process fared would serve a greater public interest. For instance, were the arrangements for each exercise adequate? Were people registered or able to vote? For example, Nigerians have till date not known how the Electoral Commission in 1991 in respect of the delimitation of electoral constituencies arrived at 5, 575 wards for the country. This has led to the fear in certain circles that there is what is known as Gerrymandering in Nigeria's electoral process, a feature in which a favoured candidate has more election centres in his areas of strength while very few centres are allocated to areas where his opponent has his main supporters.

\section{Conclusion}

This paper has restricted itself to the role of the media in the electoral process with particular reference to Nigeria. In doing so it has examined the various obstacles that have affected the performance of the media in Nigeria's electoral process. While in a sense it can be said that some improvements have been 
recorded by Nigerian media in the critical area of electioneering campaign since 1993, however, from what we have said, the Nigerian media may need to improve their coverage of politics and elections. But any assessment of the media must take into consideration the legal, normative and economic factors which constrain their performance. We need to note that although media functions are the same everywhere, they are not and cannot be performed the same way in every society. Indeed the performance of each nation's institutions is contingent upon the nation's level of development, its literacy rate, its culture and general disposition. To this extent, every nation gets the media it deserves. It therefore, implies that the media in any country are propelled not only by news content but more by societal values. The Nigerian Constitution does not empower the media. Although Section 22 of the Constitution singles out the media for the tedious task of making government accountable to the people, rather, it generalizes the freedom of speech and protects owners and not media practioners. This is a far cry from the practice in advanced democracies. For instance, according to the American Constitution, "congress shall make no laws restricting the press".

In the coverage of politics and elections, the greatest challenge of the Nigerian media is that proprietors who are mostly persons with political interests discourage them from adhering to the fundamental principles of balance and objectivity. In addition, the Nigeria media workers are poorly paid compared to the work they do. Finally, while it can be said that there are some internal problems that hinder the media, there are also some official factors. For the media to achieve these goals, it is also important to attack the inhibitory practices to achieve full media coverage of the electoral processes. 
Fidelis Chuka Aghamelu is of the Department of Philosophy, Nnamdi Azikiwe University, Awka Nigeria

\section{References}

Adamun Ogunsanwo (1982), Nigeria: The making of the presidential system 1979 General Elections, Kano, Triumph Publishing Company Ltd.

Adedeji, A. (1991), Educational Policy for socio-economic development in Africa, the challenges of the 1990s. United Nations Economic Commission for Africa.

Agba, P.C (2007) "Role of mass media in electioneering campaign in a developing context" in Ikechukwu Nwosu et al (eds) communication for sustainable human development, Enugu, African council for communication education.

Akpan, E. (1985) "Broadcast Journalism in a multi-party state" in Nwuneli, O (ed) Mass Communication in Nigeria, fourth Dimention publishers Enugu.

Alao, D (1992) News reporting, lagos unique publications. Anifowoshe, R. (2006), Violence and Politics in Nigeria, Enugu, NOIL Publishers.

Becker, S. and Lower, E (1976) "Broadcasting in presidential campaigns 1960-1970" in S. Krens (ed). The Great Debates, Carter Vs Ford, Bloomington, Indiana University press.

Ciroma, A (2005) "The 2004 local government elections in Nigeria", Extract from point blank, NTA Interview Programme. June.

Cohen, (1970). The press and foreign policy, New Jersey, Princeton university press. 
Dare, L (1985) "Politics since independence" in R. Olanigan (ed) Nigerian History and Culture, Hong Kong, Longman Group Ltd.

Dukor, M. (1998) "The state and the media in Africa" in Dukor (ed) Philosophy and politics discourse on values and power in Africa, Lagos. O.O.P Ltd.

Edogbo .O (1999) "Agenda setting role of the mass media" in C. Okigbo (ed) Reporting politics and public affairs, Nairobi, English Press.

Egbon, M. (2004) "Broadcast ethics" A paper presented at the General Assembly of the broadcasting organisation of Nigeria, Jos November.

Iredia T.O. (2007). "Information dissemination, voters mobilization and election monitoring in Nigerian electoral process: in Ogun $M$ (ed) improving the fortunes and destiny of Nigeria through the Ballot Box, Abuja, publication of the catholic laity council of Nigeria.

Kalu O.U(1985) Religion and Political Values in Nigeria:A Pluralistic Perspective. Nsukka,University Press.

Louis,C. (1971) Reporting: An inside view, varlifonia, Journal press.

Mohammed, J. (1994), "Writing political features" in C. Okigbo (ed) reporting politics and public affairs, Nairobi, English press.

Nwaozuzu (1999) "Reporting Elections in Developing Nations" in D. Koroma (ed) mass communication and nation building Vol. I. Maidguri, University of Maiduguru Press.

Okolo, C.B (1993). African Social and Political Philosophy, Nsukka, Fullodu Stappel (1973) "The challenges facing the mass media in Nigeria transistion to Civil Rules" in 
Agba (ed) Journal of liberal studies Vol. 6, Nos. 1 and 2 March.

Uzuegbunam, A. (1997) "Government and Politics in Nigeria, Characteristics, problems and prospects" In B. Lffili (ed) modern textbook on social sciences, Enugu, Joen Associates. 